\title{
永久凍土の融解過程に及ぼす 地形効果の観測的研究 OBSERVATIONAL STUDY ON TOPOGRAPHIC EFFECTS OF PERMAFROST MELTING PROCESSES
}

\author{
石平 博1 ・ 小池俊雄 2,3 ・広瀬望 4 ・ \\ SHEN Yongping5 - WANG Shaoling 6 - YE Bosheng7 \\ Hiroshi ISHIDAIRA, Toshio KOIKE and Nozomu HIROSE \\ Yongping SHEN, Shaoling WANG, Bosheng YE
}

\begin{abstract}
1正会員 工博 山梨大学講師 工学部土木環境工学科 (†400-8511 山梨県甲府市武田4-3-11)
2正会員 工博 長岡技術科学大学助教授 環境・建設系 (†940-2188 新渴県長岡市上富岡町1603-1)

3地球フロンティア研究システム地球変動研究所（テ105-6791 東京都港区芝浦1-2-1シーバンスN7F）

4 学生会員 長岡技術科学大学大学院（†940-2188 新渴県長岡市上富岡町1603-1)

5 Ph.D., Associate Professor, Lanzhou Inst, of Glaciology and Geocryology, Chinese Academy of Sciences, China

${ }^{6}$ Senior Engineer, Lanzhou Inst, of Glaciology and Geocryology, Chinese Academy of Sciences, China

${ }^{7}$ Associate Professor, Lanzhou Inst, of Glaciology and Geocryology, Chinese Academy of Sciences, China
\end{abstract}

\begin{abstract}
Spatial and temporal variability of soil moisture is considered to have significant effects on energy and water transfer between land surface and atmosphere. One of the key effects on soil moisture distribution is topographic effect, that is, wet valley and dry hill top affected by surface and sub-surface flow along slope. Then, upward and downward heat and moisture fluxes controlled by Bowen ratio and soil heat transfer parameters determined by soil moisture also vary according to topography. In the permafrost regions, the effect of topography on heat and water transfer can be observed more clearly during melting season.

The purpose of this study is to understand the topographic effect on heat and water transfer in permafrost regions. The topographic effects on permafrost hydrological conditions were examined by the pit observations which were carried out on the Tibetan Plateau as a part of the GAME-Tibet project.
\end{abstract}

Key Words : permafrost hydrology, heat and water transfer, topographic effect

\section{1. はじめに}

高い精度での気候変動予測や長期気象予報、さらには それに基づく長期的・安定的な水資源開発や洪水予測を 実現するためには、大陸, 地球規模での水・エネルギー 循環過程を理解し、これを気候・気象モデル中に反映さ せる技術を開発する必要がある。しかしながら、陸域に は様々な地表面状態が存在し、その地表面状態の違いに よって熱・水フラックスも大きく異なることから、広域 場における大気一陸域間での熱・水輸送量を正しく見積 もることは非常に困難である。さらに、この不均一性は 非常に細かなスケールにまで見られ、気候モデルのグ リッドのスケール(数10〜100km四方)においても地表面 の状態は均質とはみなせない場合が多い。したがって、 大気一陸域間での水・エネルギー循環を評価するために は、気候モデルのグリッドスケールにおける平均的な地 表面水文状態の表現やその不均一性を考慮した空間平均 的フラックスの算定手法を開発する必要がある。

このような地表面状態の不均一性が領域平均フラック スに与える影響を考える上で、とりわけ土境水分の時空 間分布の影響は大きいと考えられる。気候システムにお ける土壌水分の重要性については、鼎ほがににレビュー されている通りであるが、気候モデルのグリッドスケー ルでの土垬水分分布と領域平均フラックスの関係につい 
ても近年検討が成されている。仲江川ほがは、対象と する領域内における物理量の分布を考慮できる蒸発量算 定式を導出し、これを用いた数值実験により表層土培水 分量と地表面温度の分布が蒸発量計算に及ぼす影響につ いて検討した結果、表層土鎧水分や地表面温度の分布の 効果は平均、分散のみならずその分布形状によっても異 なることを示している。また、Chen et al. ${ }^{31}$ は、土壌特 性及び土壌水分状態が分布している場における不飽和流 を表現するモデルを提案し、寺川ほがは、Chen et al. の手法を組み込んだメソスケール水文・気象モデルを用 いて、地球温暖化に伴う日本周辺領域で気温, 降水量等 の変化に関するシミュレーションを行っている。

このように領域平均フラックスを評価する上で土㙋水 分分布は非常に重要であることが示されてきたが、その 分布を作り出す要因の 1 つとして地形勾配に応じて発生

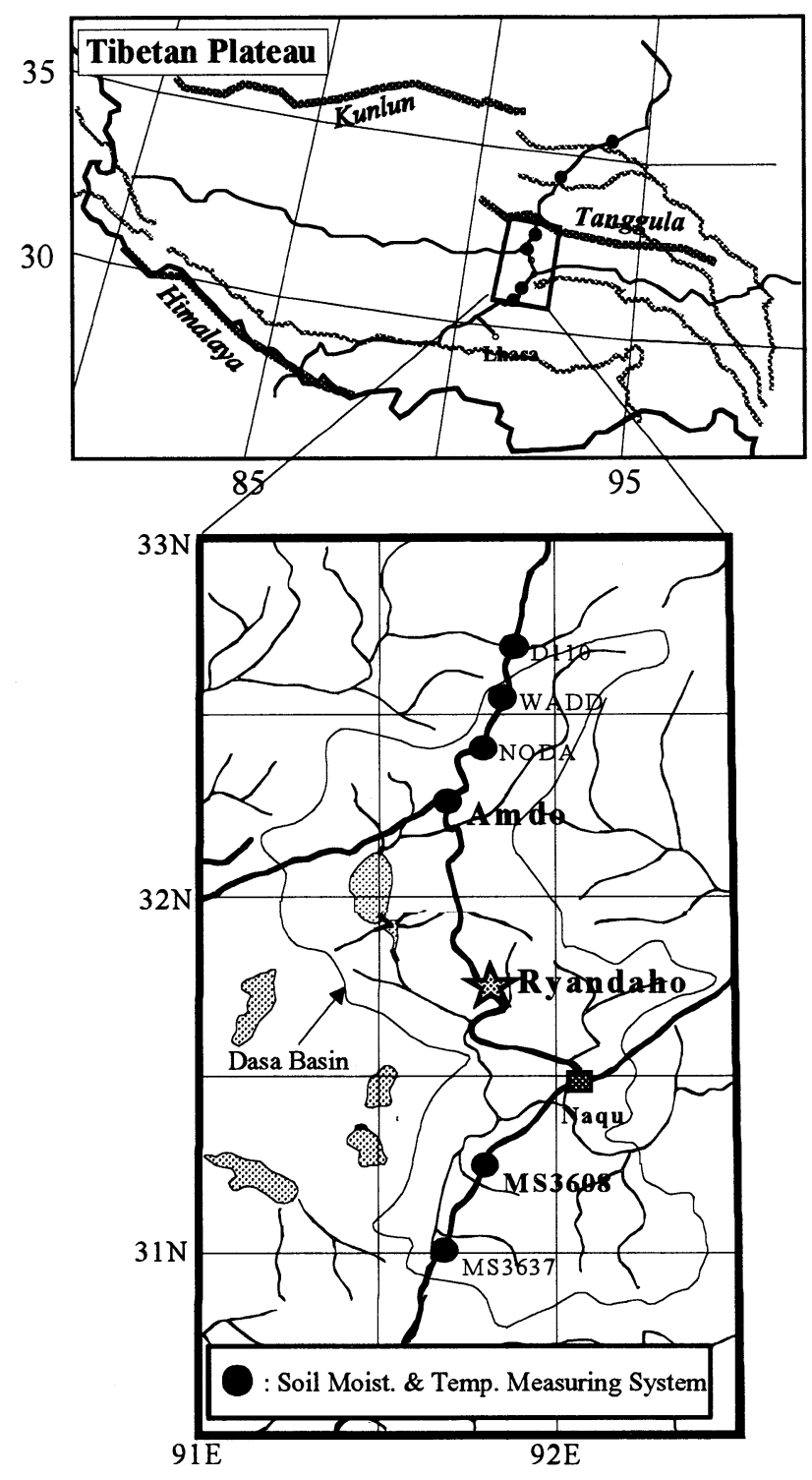

図-1 観測対象領域の概要
する斜面方向への水移動が考えられる。地形起伏の存在 する領域では、斜面上部から下部へ向かって地下水の移 動があるため、谷地形の部分では定常的に水分供給され 湿潤化し、斜面上部では逆に乾燥しやすくなることが予 想される。この地形によって作り出される土堙水分分布 が潜熱・顕熱フラックスに与える影響に関する検討とし ては、田中ほが，田中ほが，石平ほがなどがあるが、 いずれも仮想的な条件下での数值シミュレーションによ るものあり、現地観測デー夕に基づく検証などはまだ十 分には行われていない。

そこで本研究では、チベット高原の永久凍土帯に位置 する斜面での地温, 土㙴水分の観測結果を用いて、斜面 方向への水分移動がその場における熱・水循環に与える 影響について検討する。ここで、チベット高原の永久凍 土帯を対象領域として選んだのは以下の理由からである。 まず、第一に森林のような植生が存在しないためその影 響を考慮する必要が無く、地表面での熱・水輸送過程を より単純化して考えることができること、第二に平坦な 平原の中に小高い丘が点在しており、観測に適したス ケールの独立した斜面を選定できること、第三に、永久 凍土層の季節的な融解及び東結は、土袞水分の供給とと もに凍土融解深変化による土壤保水容量の季節的変化を 生み出すなど、土埕中の熱・水輸送の関係がより顕著に あらわれると考えられることなどが挙げられる。これに 加え、チベット高原やシベリアに広がる永久凍土層は、 土䇎水分の季節変動の支配要因、あるいは年々変動を駆 動するメモリーとしての機能の面から、アジアモンスー ン変動へ大きな影響を与えると考えられており、アジア 域における気候システムを考える上でも重要な地域であ

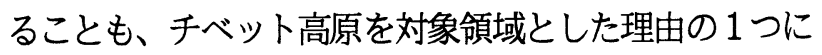
挙げられる。

特に本研究では、土靖水分, 地温の鉛直プロファイル および凍土融解深に着目し、それらの斜面方向の分布状 態とその季節変化加永久凍土帯における熱・水輸送に おける斜面流の効果について検討した。

\section{2. 対象領域および観測概要}

図ー 1 はGAME-Tibet Projectにおける観測対象領域の 概要を表しており、今回の斜面水文観測はチベット高原 中央部 (N31 ${ }^{\circ} 49^{\prime}, \mathrm{E} 91^{\circ} 44^{\prime}$ 近辺) に位置する両道河 (Ryandaho, 図中方)地点において行われた。この地点に おける水準測量により得られた斜面の縦断形状を図 -2 示す。全長約700m, 高低差約80mの南西向き斜面であり、 斜面下端から距離約 $500 \mathrm{~m}$ までは平均斜度 $3 \sim 4^{\circ}$ の緩やか な勾配が続き、斜度が12 130 の比較的急勾配斜面がこ れに続く。この斜面において、斜面下部(№.1), 斜面途 中(No.2), 地形変曲点(No.3), 斜面上部(No.4)の 4 力所 に観測用縦穴を掘り、TDR土㙴水分計による土堙水分観 
表-1 凍土帯斜面水文観測の概要

\begin{tabular}{|c|c|c|c|}
\hline 観測日時 & 土塎水分観測 & 地温観測 & コメント \\
\hline $98 / 05 / 08$ & No.1,2,4 & No. $1,2,4$ & 地点(No.1,2,4)とも凍結土壌に到達 \\
\hline $98 / 06 / 13$ & No.1,2,4 & No.1,2,4 & No.4地点では凍結土㙥に到達せず(磷層のため掘削できず) \\
\hline $98 / 07 / 04$ & No.1,2,4 & No.1,2,4 & No.2地点で地下水面を確認 \\
\hline $98 / 07 / 29$ & No.1,2,3 & No. $1,2,3,4$ & No.1,No.2地点で地下水面を確認, No.3地点を新たに掘削 \\
\hline $98 / 08 / 24$ & No.1,2,3 & No.1,2,3 & No.1,No.2地点で地下水面を確認, 斜面下部はほぼ全層飽和 \\
\hline $97 / 09 / 04$ & No.1,2,4 & No.1,2,4 & 斜面及ひ観測地点(No.1,2,4)の選点及び予備観測 \\
\hline
\end{tabular}

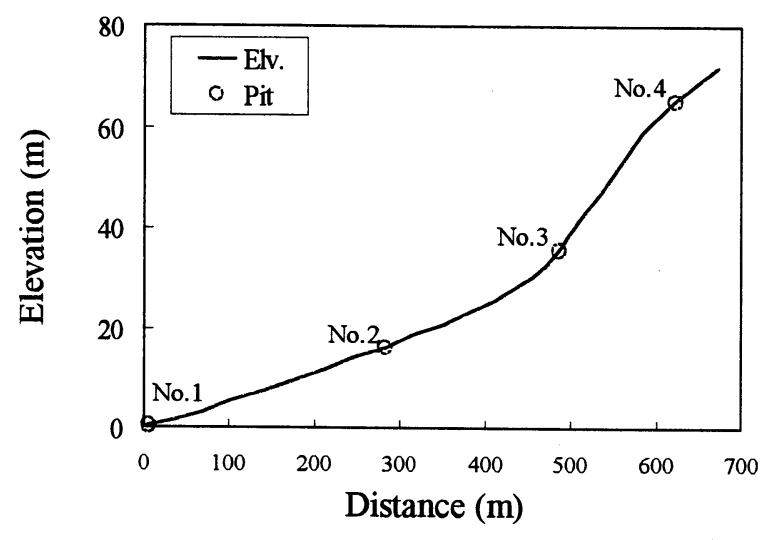

図-2 観測対象斜面縦断図

測及び温度センサによる地温の測定を、表層から約 $10 \mathrm{~cm}$ 間隔で行った。なお、観測用の縦穴の深さは、砂層など 人力による掘削が困難な層に当たらない限り、土堙凍結 面に到達する深さとした。さらに、このような土培水分， 地温プロファイルの観測を1997年9月〜1998年8月までの 期間中に計6回(表-1参照)行うことにより、斜面におけ る土壌水分, 地温分布の季節的な変化に関するデー夕を 収集した。また、8月24日の観測においては、これら縦 穴での土䫓水分観測に加え、斜面上数地点において表層 $8 \mathrm{~cm}$ の土壌水分観測も行った。

さらに、この斜面観測と同時期に、チベット高原を南 北に縦断するラインで土袞水分, 地温の自動計測システ ムによる観測も行われた(図ー1ので示す地点)。このシ ステムにより、高原上8力所における土塨水分, 地温プ ロファイルが1997年7月以降1時間間隔で得られている。 この観測システムは比較的平坦な地形条件の場所に設置 されていることから、本検討では、先に述べた斜面観測 により得られる土塨水分, 温度のプロファイルとの比較 対象としてこのデータを使用する。

\section{3. 解析結果および考察}

（1）斜面上部，下部での土壤水分，地温状態の違い 図一3は、表-1に示した観測日におけるNo.1〜№.4 地点での土塎水分, 地温プロファイルである。
表-2 土袞水分, 地温自動観測システムの概要

\begin{tabular}{|c|c|c|}
\hline センサ & センサ数 & センサ深度 \\
\hline $\begin{array}{l}\text { 土塎水分 } \\
\text { (TDR) }\end{array}$ & 6深度 & $\begin{array}{l}4 \mathrm{~cm}, 20 \mathrm{~cm}, 40 \mathrm{~cm}, 60 \mathrm{~cm}, \\
100 \mathrm{~cm}, 160 \mathrm{~cm}, \text { Bottom* }\end{array}$ \\
\hline $\begin{array}{l}\text { 地温 } \\
\text { (Pts) }\end{array}$ & 10深度 & $\begin{array}{l}4 \mathrm{~cm}, 20 \mathrm{~cm}, 40 \mathrm{~cm}, 60 \mathrm{~cm}, \\
80 \mathrm{~cm}, 100 \mathrm{~cm}, 130 \mathrm{~cm}, \\
200 \mathrm{~cm}, \text { Bottom* }\end{array}$ \\
\hline
\end{tabular}

まず、斜面方向の土壌水分の分布パターンについて見 ると、全般的に斜面下部(№.1)では湿潤状態となる一方、 斜面上部(No.3,4)では逆に乾燥化する傾向が見られる。 今回観測を行った斜面のスケールでは、降水量の空間分 布は無視できると考えられることから、このような斜面 方向の土塞水分分布を作り出す要因として、先に述べた 斜面方向への地下水の移動が挙げられる。つまり、降雨 浸透や凍土融解により土層中に貯留された水分が、地形 勾配によって斜面の上部から下部へと流下するため、上 流から水分供給を受ける斜面下部は湿潤化し、斜面上部 ではト流へ水分が移動した分だけ乾燥化することとなる。

一方、地温について同様に見てみると、斜面上部では 地温が高く、斜面下部では低温となる傾向が確認される。 このような地温分布を作り出す要因としては、先ほど述 べた斜面上部と下部での土袞水分量の違いが挙げられる。 具体的には、土䫓水分状態に応じて、地表面熱収支や土 袞の熱特性が変化することによるものと考えられる。土 塞水分が高く、蒸発可能な水分が十分にある場合には、 地表面熱収支における潜熱の割合が増えることから、地 中へ輸送される熱量は減少する一方、乾燥した土㗒面に おいては、蒸発抑制により潜熱の割合が減少し、結果と して地中への熱輸送が増えると考えられる。図一4は、 98年8月24日の観測において測定された、表層土穓水分 (地表面から深さ $8 \mathrm{~cm}$ までの平均土壌水分)の斜面方向分 布を表しているが、この図からも斜面上部と下部では表 層土壌水分に明暸な差があることか確認できる。さらに、 表層土壌水分の多寡により蒸発効率は大きく変化するこ とから (近藤) 
[1998/5/8] Temperature (deg-C)

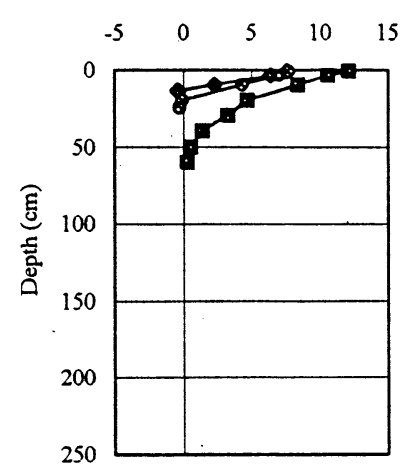

[1998/6/13] Temperature (deg-C)

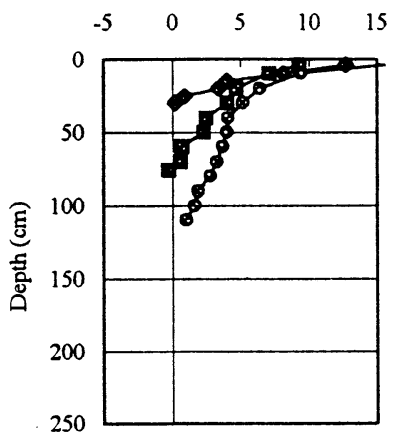

[1998/7/4] . Temperature (deg-C)

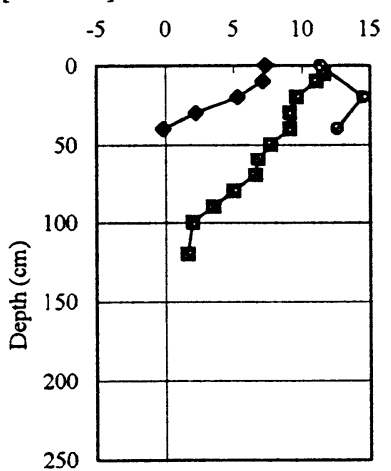

Moisture Content (\%)

$\begin{array}{llllllll}0 & 10 & 20 & 30 & 40 & 50 & 60 & 70\end{array}$

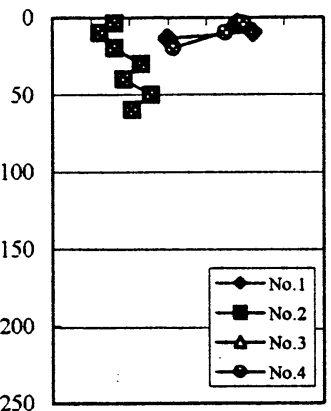

Moisture Content (\%)
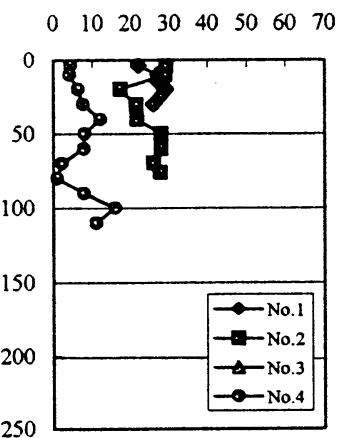

Moisture Content (\%)

$\begin{array}{llllllll}0 & 10 & 20 & 30 & 40 & 50 & 60 & 70\end{array}$

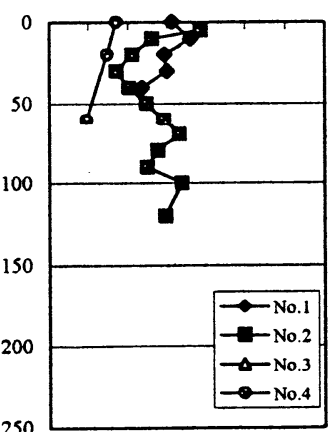

[1998/7/29] Temperature (deg-C)

Moisture Content (\%)

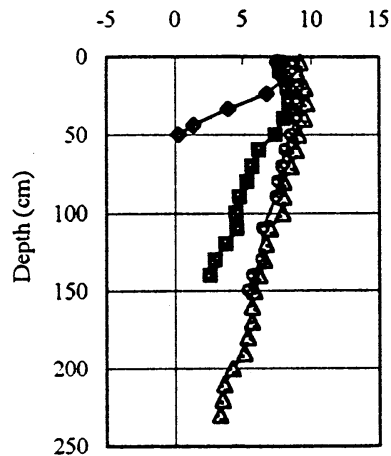

[1998/8/24] 'Temperature (deg-C)

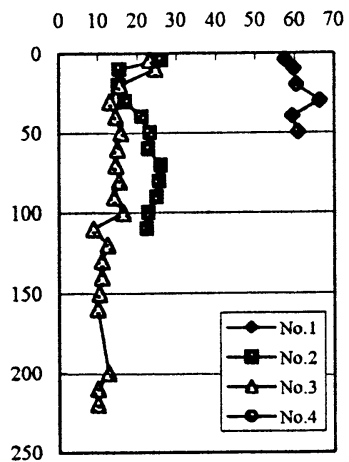

Moisture Content (\%)

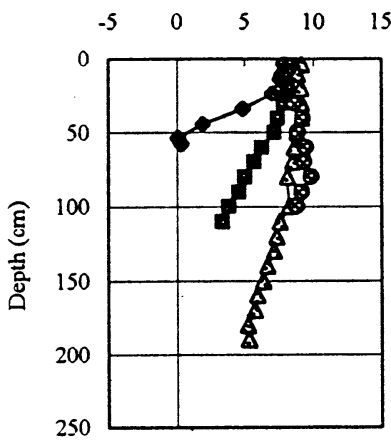

[1997/9/4] Temperature (deg-C)
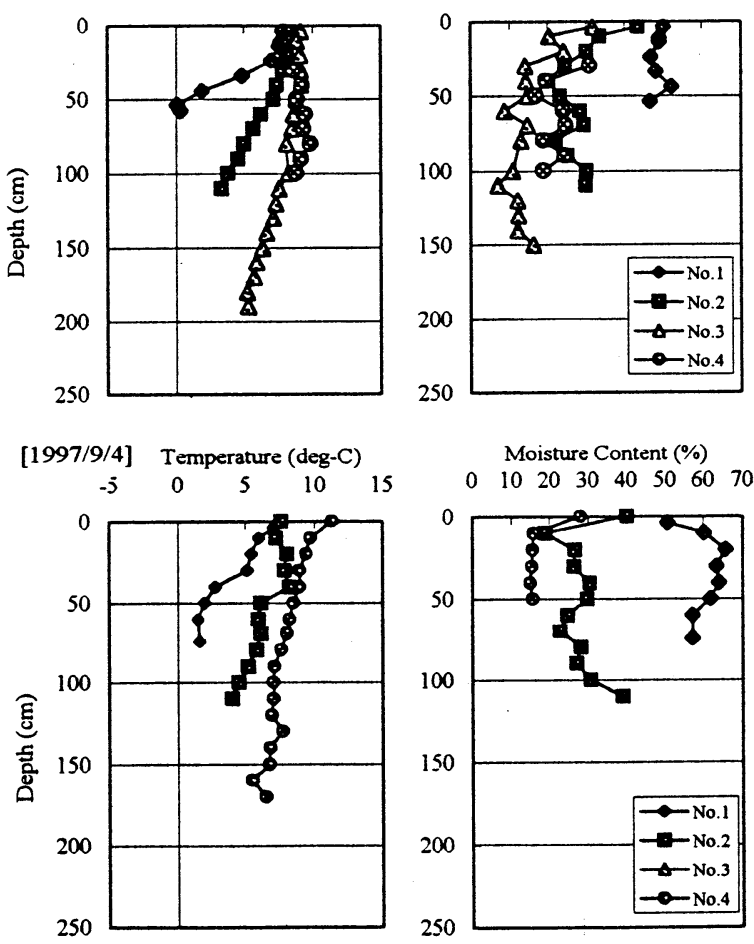

Moisture Content (\%)

$\begin{array}{llllllll}0 & 10 & 20 & 30 & 40 & 50 & 60 & 70\end{array}$

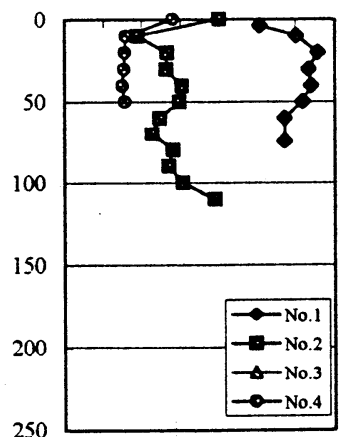

図-3 斜面における地温，土鎧水分プロファイルの季節変化

性は大きく異なり、その違いが温度の差となって現れた と考えられる。さらに、このような地表面熱収支だけで なく、土嚊の含水状態の違いは、地中での熱伝導特性に も影響を与える。土境の熱容量は、一般に土粒子と土境 水それぞれの熱容量を体積割合に応じて平均することに より求められるが、土蚟水分か増大すると、熱容量が相 対的に大きい水の割合が増えるため、土境の熱容量も大 きくなる。つまり、土壇水分の増加とともに土層は暖ま りにくくなるといえる。これによって、土境水分が高い 斜面下部での地温か低く保たれ，乾燥した斜面上部では、 相対的に暖まりやすくなったとも考えられる。ただし、
土堎水分の増加とともに、空陌が水で満たされるため熱 伝導率は高くなることから、土埣水分の増加が熱伝導率 に与える影響は、熱容量のそれと全く逆の傾向を示す。 したがって、土境水分状態の違いが土層全体の温度に対 して与える影響については、数值モデルによるシミュ レーションなどを通じさらに検討する必要がある。

以上のように、斜面上部からの土境水の流下か斜面上 部を乾燥・高温化し、斜面下部を湿潤・低温化する傾向 か確認された。

（2）斜面における土境水分, 地温分布の季節的な変化

斜面上部と下部では、土堎水分, 地温の状態が異なる 


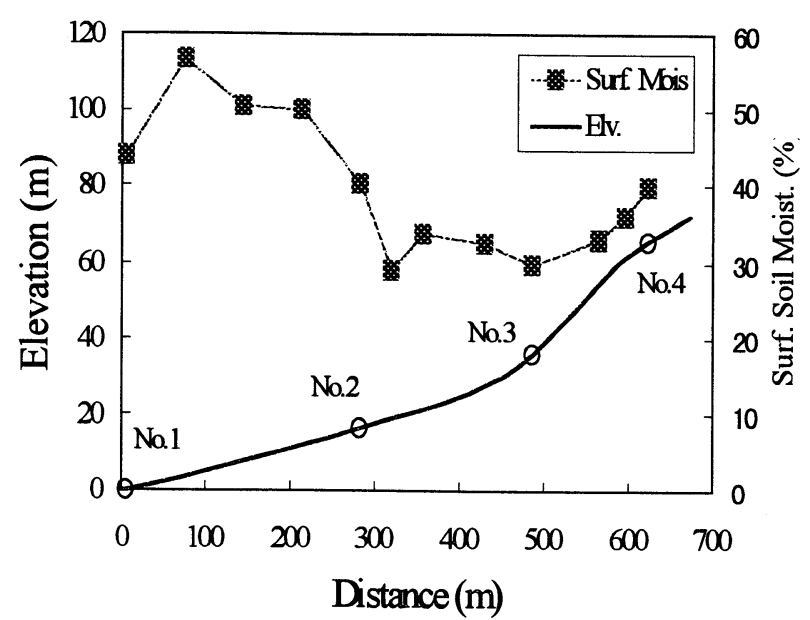

図-4 斜面における表層土境水分分布 (1998/8/24)

ことについて述べてきたが、次にこのような土㙴水分や 地温の斜面方向分布の季節変化について述べる。図ー 3 に示した土堙水分，地温プロファイルを、時間経過に 沿って見てみると、季節の進行とともに斜面上部と下部 での土培水分，地温の差異が大きくなる傾向が見られる。 たとえば、98年5月8日の地温プロファイルを見ると、 №.1,2.4の各地点間の温度差はさほど大きくなく、プロ ファイルの形状にもさほど大きな違いは見られない。し かしながら、季節の進行とともにその差は大きくなり、 8月24日の土㙵水分, 地温については、No.1〜3の各地点 での值に明瞭な差異が認められる。また、同日の地温プ ロファイルについては、各地点ごとにその形状(温度の 変化率)も大きく異なっている。

このような季節変化については、凍土融解に伴う斜面 方向への水分移動量の変化が関与していると考えられる。 まず、凍土融解の初期段階(4〜 5月)においては、融解深 は浅く、土㙵中における移動可能な液相水がまだ十分に 蓄積されていないため、斜面方向への水分移動量はさほ ど多くない。これに対し、凍土融解が進行した7〜8月に おいては、凍土融解や降雨浸透により土境層の貯水量が 増加することに加え、凍土層が止水面として機能するた めに、その土袞水が凍土層上に飽和水帯を形成し、斜面 方向への飽和側方流が発生する。これにより、多量の水 分が斜面上部から下部へと輸送されることとなり、その 結果、斜面上部と下部とで水分，温度状態が大きく変化 すると考えられる。今回の観測においても、№.2地点に おいて、5月の段階では見られなかった地下水面が 7 月 以降 3 回の観測ではいずれも確認されるなど、凍土融解 の進行にともなう飽和水帯の形成を裏付ける観測結果が 得られている。

\section{（3）凍土融解深に与える斜面流の影響}

永久凍土帯における熱・水輸送過程を考えるうえで、 凍土融解深は重要な要素の 1 つである。これは、永久凍

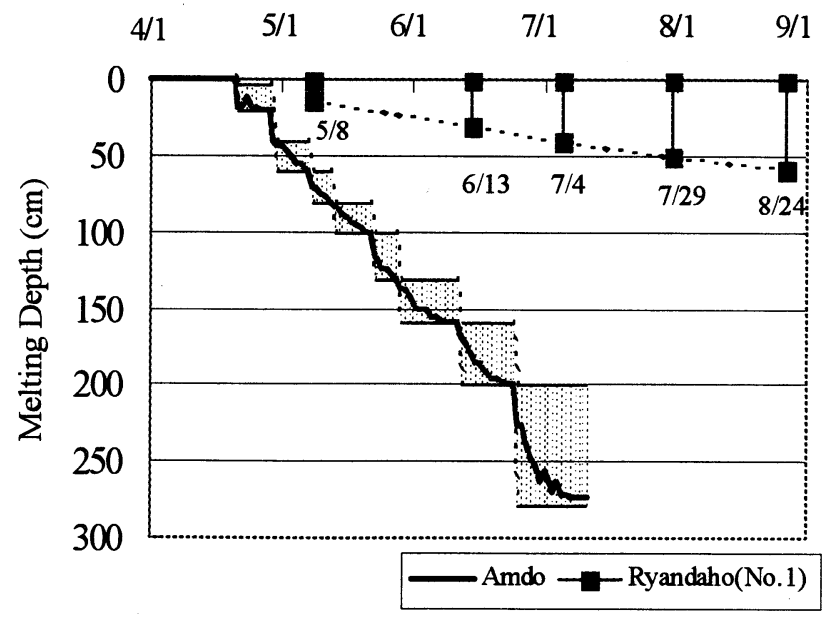

図-5 斜面及び平坦地における凍土融解深の変化

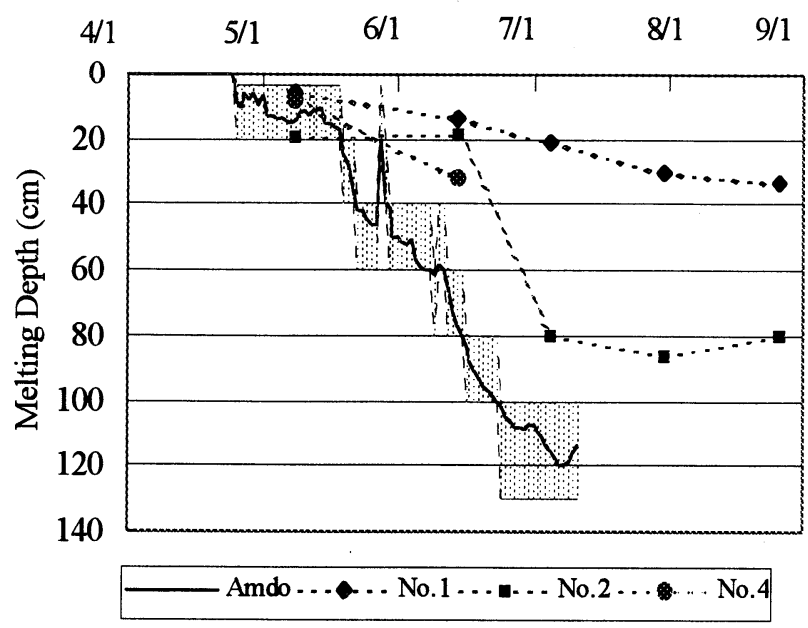

図-6 斜面及び平坦地における等温面 $\left(5^{\circ} \mathrm{C}\right)$ 深さの変化

土層の融解深の変化は、土壌水分の供給とともに凍土融 解深変化による土袞保水容量の季節的変化を生み出すな どの働きを持つためである。ここでは、斜面が存在する ことにより、この融解深の季節変化がどのように影響を 受けるのかについて検討した。図一5は、斜面下部に位 置するNo.1地点で観測された凍土融解深と、土䇎水分, 地温の自動観測システム設置地点の 1 つであるAmdo地点 における地温測定結果から推定した涷土融解深とを比較 したものである。なお、Amdo地点における凍土融解深の 推定については、観測により得られた地温プロファイル から地温が $0{ }^{\circ} \mathrm{C}$ となる深度が存在する層(図中ハッチの部 分)を特定し、これを融解深とした。またハッチの中の 実線は、地温プロファイルの線形補間により地温が $0^{\circ} \mathrm{C}$ となる位置を求めたものである。斜面観測を実施した両 道河とAmdoとでは、気象条件も異なると考えられること から、Amdoにおける融解深と斜面のNo.1地点におけるそ れとを単純に比較することはできないが、融解のスピー ドという点について見た場合、平坦地であるAmdoと比較 
して、No.1地点における融解の進行は緩やかである。こ れは、先ほど述べたように斜面方向への流れが斜面下部 を湿潤，低温化するためである。また同様に、斜面及び Amdo地点における地温プロファイルから地温が $+5^{\circ} \mathrm{C}$ とな る深さを求めプロットしたものが、図ー6であるが、や はり斜面上部よりも斜面下部での温度変化が緩やかであ ることが分かる。また、これらの結果より、斜面の上部 ではこれと逆のメカニズムにより、平坦地よりも融解深 が深くなることが予想される。

以上のように、斜面方向への土壃水の移動は、凍土融 解深の分布をも作り出すことが示されたが、このように して形成される融解深分布は、先に述べた土壌水分や土 猿保水容量などの不均一性を生み出すことを通じ、広域 場におけるフラックスに影響を与えることも考えられる。

\section{4. まとめ}

チベット高原の永久凍土帯における斜面水分観測(土 壌分, 地温観測)デー夕をもとに、斜面方向への地下水 の輸送が熱・水輸送過程に与える影響(地形効果)につい て検討した結果、以下の知見が得られた。

（1）斜面上部からの土㙵水の供給により、斜面上部は乾 燥・高温化し、斜面下部は湿潤・低温化する傾向が 見られる。

（2）斜面方向の土壌水分, 地温分布の季節変化にも、斜 面方向への地下水移動が関与していることが考えら れる。具体的には、凍土融解にともなう飽和水帯の 形成ならびに斜面側方流の発生がこの季節変化に影 響を与えていることが予想される。

（3）地形勾配による斜面方向への水分移動は、凍土融解 深の分布にも影響を与えている可能性がある。

本検討により得られた知見をもとに、今後は斜面による 水分輸送過程を考慮した熱・水輸送モデルの開発ならび
に、今回述べたような地形効果が領域平圴フラックスに 与える影響についても検討を行う予定である。

謝辞：本研究は文部省国際共同研究等経費「アジア モンスーンエネルギー・水偱環観測研究計画(GAME)」, 科学研究費補助金(国際学術共同研究)「チベット高原に おけるエネルギー・水循環過程の研究」、地球フロン ティア研究システム (陸域寒冷圏) の研究成果の一部で ある。本研究では, GAME-Tibetプロジェクトを通して得 られたデータを使用している.

\section{参考文献}

1) 鼎信次郎, 沖大幹, 虫明功臣 : 気候システムにおける土䫓水 分, 水文・水資源学会誌, Vol.11 No.5, pp. 508-514. 1998.

2) 仲江川敏之, 沖大幹, 虫明功臣 : サブグリッドスケールの分 布を考虑した蒸発量の算定について, 水工学論文集, 第38巻, pp.167-172, 1994.

3) Chen, Z. Q., Govindaraju, R. S. and Kavvas M. L. : Spatial averaging of unsaturated flow equation under infiltration condition over areally heterogeneous field 1 . Development of models, Water Resouces Research, vol. 30 No.2, pp.523-533. 1994.

4) 寺川陽, 吉谷純一, 渡辺明英, 藤兼雅和, 松浦達郎 : 地球温 暖化が日本域における水文循環に及ぼす影響の予測に関する 研究報告書, 土木研究所資料, 第3432号, 1996.

5) 田中賢治, 前田敏彦, 池淵周一 : 地表面起伏形状と水・熱入 ラックス分布の関係, 水文・水資源学会1995年研究発表会要 旨集, pp.54-55, 1995

6)田中賢治, 前田敏彦, 高棹玩馬, 池淵周一 : 陸面モデルのた めの 2 次元地中モデルの開発, 水工学論文集, 第 41 巻, pp.93-98, 1997.

7) 石平博, 小池俊雄, 陸旻皎, 広瀬望 : 永久凍土帯の熱 - 水移 動特性に関する 2 次元地中流モデルの開発, 水工学論文集, 第42巻, pp.133-138, 1998.

8) 近藤純正 : 水環境の気象学, 朝倉書店, 1994.

(1998. 9. 30受付) 